\title{
"Portfolio selection strategies and cognitive psychology biases: a behavioral evidence from the Nigerian equity market"
}

\begin{tabular}{|c|c|}
\hline AUTHORS & $\begin{array}{l}\text { Mukail Aremu Akinde (D https://orcid.org/0000-0002-1677-3564 } \\
\text { Eriki Peter } \\
\text { Ochei Ailemen Ikpefan }\end{array}$ \\
\hline ARTICLE INFO & $\begin{array}{l}\text { Mukail Aremu Akinde, Eriki Peter and Ochei Ailemen Ikpefan (2018). Portfolio } \\
\text { selection strategies and cognitive psychology biases: a behavioral evidence from } \\
\text { the Nigerian equity market. Investment Management and Financial Innovations, } \\
\text { 15(3), 267-282. doi:10.21511/imfi.15(3).2018.22 }\end{array}$ \\
\hline DOI & http://dx.doi.org/10.21511/imfi.15(3).2018.22 \\
\hline RELEASED ON & Friday, 14 September 2018 \\
\hline RECEIVED ON & Thursday, 24 May 2018 \\
\hline ACCEPTED ON & Tuesday, 14 August 2018 \\
\hline LICENSE & $\begin{array}{l}(c) \text { EY-NG } \\
\text { This work is licensed under a Creative Commons Attribution-NonCommercial } 4.0 \\
\text { International License }\end{array}$ \\
\hline JOURNAL & "Investment Management and Financial Innovations" \\
\hline ISSN PRINT & $1810-4967$ \\
\hline ISSN ONLINE & $1812-9358$ \\
\hline PUBLISHER & LLC "Consulting Publishing Company "Business Perspectives" \\
\hline FOUNDER & LLC "Consulting Publishing Company "Business Perspectives" \\
\hline
\end{tabular}

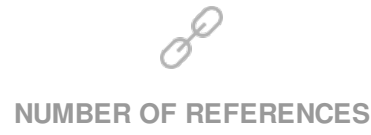

49

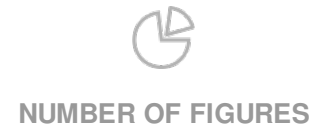

0

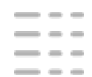

NUMBER OF TABLES

16

(C) The author(s) 2022. This publication is an open access article. 


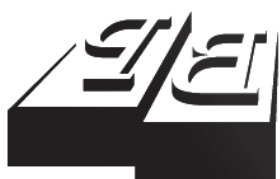

BUSINESS PERSPECTIVES

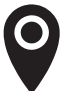

LLC “CPC "Business Perspectives" Hryhorii Skovoroda lane, 10, Sumy, 40022, Ukraine

www.businessperspectives.org

Received on: $24^{\text {th }}$ of May, 2018 Accepted on: $14^{\text {th }}$ of August, 2018

(C) Mukail Aremu Akinde, Eriki Peter Ochei Ailemen Ikpefan, 2018

Mukail Aremu Akinde, Ph.D. Student in Finance, Covenant University, Ota, Ogun State, Nigeria.

Eriki Peter, Visiting Professor of Finance, Covenant University, Ota, Ogun State, University of Benin, Nigeria.

Ochei Ailemen Ikpefan, Professor of Finance, Covenant University, Ota, Ogun State, Nigeria.

\section{(ㄷ)(1) $(8)$}

This is an Open Access article, distributed under the terms of the Creative Commons Attribution-NonCommercial 4.0 International license, which permits re-use, distribution, and reproduction, provided the materials aren't used for commercial purposes and the original work is properly cited.
PORTFOLIO SELECTION

STRATEGIES AND COGNITIVE PSYCHOLOGY BIASES:

\section{A BEHAVIORAL EVIDENCE FROM THE NIGERIAN EQUITY MARKET}

\begin{abstract}
The empirical evidence in the developed equity markets such as the United States, the United Kingdom, Germany, Japan and emerging markets had pronounced that there are institutional and individual investors' cognitive psychology and mental biases in favor of the Growth Stocks, that is, the Growth Stocks are always preferred to the Value Stocks by the investors. The investors most times prefer the Growth Stocks to the Value Stocks irrespective of the stock fundamentals behavior in the equity market. The paper investigated whether Cognitive Psychology and Mental biases affect Portfolio Selection strategies using the Growth or the Value Stocks investment styles in the Nigerian Stock Market. In the study, the summary of the primary data was described and Multinomial Logistic Regression (MLR) models were adopted to make inferential decisions. The paper collected primary data through questionnaire administered to individual and institutional investors on the floor of Nigeria Stock Exchange (NSE). The findings from the analyses conducted confirmed a strong existence of Cognitive Psychology and mental biases in favor of the Growth Stocks in the Nigerian Equity Market. Investors had more belief in Growth Stocks than the Value Stocks notwithstanding the behavior of the market fundamentals. The study recommended that investors should seriously consider occurrences and performance fundamentals in Portfolio Selection in the Nigerian Equity Market.
\end{abstract}

\section{Keywords}

cognitive psychology, mental biases, portfolio selection, investment styles, growth stocks, value stocks

\section{JEL Classification G11, G12}

\section{INTRODUCTION}

In the traditional and modern theories of finance, there are various popular portfolio selection strategies that are adopted in the stock markets: these include Capital Assets Pricing Model (CAPM), Arbitrage Pricing Model (APM), efficiency of equity market, dividend relevancy and irrelevancy theories, contrarian investment philosophy, concentration or diversification paradigms, growth and value stocks investing styles, mental and behavioral approaches to investments. The traditional finance tenet of the stock market presupposes that investors are not only rational; they are unprejudiced in decision making on investment. The new theories of finance, unlike the traditional ones, are premised on the doctrine of irrationality and illogical behavior of investors in maximizing returns and risk minimization in the equity markets. The behavioral finance doctrine, according to Hirschey and Nofsinger (2008), provides a new philosophy popularized by Daniel Khahneman, a psychologist and a Nobel Laureate winner, who postulates that investors are over-sensational, they infrequently behave irrationally by over-estimating their judgement skills in the process of 
choosing stocks in the equity market. The investors follow the trajectory of illogical paths to maximize returns and minimize risk in the equity markets. This brings about discussion on the new cognitive psychology and mental accounting theories in modern behavioral finance.

Growth and value stocks investing approaches are modern portfolio selection strategies and behavioral theories that could be deployed by investors to maximize returns and minimize risk in the equity markets. Growth stocks, according to Francis et al. (2000), Faerber (2000), Graham and Dodd (1934), Buffett (1984) and Jones (2010), are stocks which are mostly wanted by the investors. The growth stocks, according to Cronqvist et al. (2013), are preferred by the wealthy investors. Such stocks usually exhibit sustained and rapid growth in revenues, highly priced stocks, higher Price Earnings Ratio (PER), price to book, and low dividend yield than the value stocks. On the other hands, value stocks are unwanted lowly priced stocks, such stocks have higher Dividend Yield (DY) but with disappointing earnings, lower price to book ratio and Price Earnings Ratio (PER), among other disappointing financial fundamentals. Value stocks according to Faerber (2000) and Vorwerg (2015), are demanded by the patient investors and growth stocks are demanded by un-patient investors.

A rational investor maximizes returns and minimizes risk (Mahina et al., 2017; Olowe, 2008; Pandey, 2006). Contrary to this traditional investment paradigm, the examination of cognitive psychology puzzle is currently the focus of empirical investigations across the developed, emerging and developing stock markets. It appears there is a strong cognitive psychology bias in favor of the growth stocks. Cognitive psychology bias, as explained by Hirschey and Nofsinger (2008), means overestimation or over-sensationalizing of good or bad performance fundamentals obtained from the financial statements of entities quoted on the floor of a stock market. The empirical evidence includes the studies by Miwa and Ueda (2014) and Glushkov (2007) in the advanced stock markets, where sentiments significantly influenced the choice of the growth stocks; Fernández (2007) and Fernández (2009), where they provided proofs that abnormal behavior and sentiments positively affected prices of the growth stock. A few numbers of studies have contributed to the debate as to whether cognitive psychology errors influence the choice of the growth stocks or value stocks, especially in the developed and the emerging stock markets. However, there are few studies if there is any that had investigated how cognitive psychology bias affected the growth or the value stocks in the developing equity market like that of Nigeria.

The Nigerian Stock Exchange (NSE) according to Okwu (2015) was established in 1960 as Lagos Stock Exchange (LSE). It was renamed in 1977 as Nigeria Stock Exchange. The market started with 19 securities in 1961. Today, the number of securities which were 216 in the financial year 2016 rose to 278 in the year 2017. As at the year ended 2017, the NSE had a total market capitalization of N23tn and the volume of transaction stood at 171,220 billion as July, 2018, (Afrinvest West Africa, 2018; Ogunbanjo, 2017). The NSE is a lubricant to the economic growth of the country, at the last quarter of 2017, Nigeria economy exited recession, the operating profit after tax of the stock market rose from N27.45 million in 2016 to N3.79 billion in 2017; suggesting the highest operating performance in the last five (5) years. The NSE assets according Ogunbanjo (2017), rose by 19.3\% to N23.1 billion as at the year ended 2017. The All Share Index (ASI) rose from 319,488.92 points in 2016 to 385,933.35 points in 2017, representing an increase of $20.79 \%$. Similarly, the market capitalization rate rose from N109, 819.3 billion in 2016 to N133,809.5 billion in 2017, representing an increase of 20.80\%. The relative performance of the ASI to Real Gross Domestic Product portends an increase of 563.38\% in 2017 from $470.31 \%$ in 2016 and the Market Capitalization rate to Real Gross Domestic Product rose from $161.66 \%$ in 2016 to $195.37 \%$ in 2017. The NSE appears to be attractive and returns-driven market for local and international investors across the world. Besides, the market is technological driven according to Okwu (2015), it offers electronic clearing platforms through the Central Securities Clearing Systems (CSCS).

There is dearth of research on the influence of behavioral biases on stocks in the Nigerian equity market. Large numbers of academic researches focused on the traditional areas of Finance such as money 
market, volatility, exchange rate, financial liberalization, deregulation, capital market and economic development and very few efforts on the modern Behavioral Finance, (Oladeji, Ikpefan \& Alege, 2018; Isibor, Ojo \& Ikpefan, 2018; Ailmen, Akhanolu \& Chibuzor, 2016; Isibor, Ikpefan, Okafor \& Ojeka, 2016). Babajide and Adetiloye (2012) in a survey undertaken using 300 randomly to capture investors in the Nigerian equity market Lagos engaging correlation and Pearson Moment coefficient affirm a weak inverse relationship between behavioural biases and stock market performance. The study did not extend the biases to the growth and value stock portfolio strategies, besides, it is noticeable that the sample size of 300 investors may be inadequate considering the high number of investors and deals of above 4,000 on the average per day on the NSE. Currently, there is a growing discussion and serious concern in the advanced and the rapidly improving stock markets as to whether there is a cognitive psychology bias significantly influencing the choice of the growth stock (i.e., famous stocks, large cap stocks) or value stock (i.e., unpopular, low cap stocks). Despite few empirical evidence, studies are yet to confirm whether cognitive psychology biases influence the choice of the growth stocks or the value stocks on the Nigeria Stock Exchange (NSE). Encouraged to fill the gap in the theories, empirical and practice of finance, this study investigated whether cognitive psychology bias significantly affects the choice of the growth stocks or the value stocks on the Nigeria Stock Exchange (NSE).

\section{LITERATURE REVIEW}

The behavioral finance theorists provide alternative window to investors' rationality and risk minimization assumptions, investors using mental short-cut occasionally behave irrationally. Hirschey and Nofsinger (2008) in the contrarian theory of David Dreman reveal awareness of how investors could profit from illogical anxiety or absurd eagerness. The prospect paradigm developed by David Kaheman, a Nobel Laureate in 2002, documents utility theory where investors maximize value when choice is made among large alternative courses of action in the mist of uncertainty using mental shortcuts.

According to Elan (2010), the mental shortcut (mental bias) is heuristic simplification, which allows brain complex surface to give an estimate of the best options to be undertaken under extreme uncertainty. Hirschey and Nofsinger (2008) and Elan (2010) reveal that mental shortcuts bring about familiarity bias, overconfidence, sentiments, cognitive errors and representative bias. As a result of human sentiments, to see the same financial information differently, gamblers' luck is completely unnecessary; a psycho-dynamic behavioral finance as revealed by Hirschey and Nofsinger (2008) and Elan (2010) is the antidote in this instance to make effective investment decisions through reduction of cognitive errors in the stock markets. Alquraan et al. (2016) and Faerber (2000) explained the theory of over-confidence to mean a situation where investors rate their precision knowledge in relation to others and investment decision making ability above average. The theory describes abnormality and inconsistency movement of stock prices as a result of earnings announcement and other financial fundamentals.

The theory is theoretically attractive, however, certain non-financial factors, for example, poor management vision, could affect prices of stock; besides, the objective measurement criteria are vague. It premised on behavioral issues, irrationality and illogical attitudes. Similarly, Alquraan et al. (2016), and Hirschey and Nofsinger (2008) explained the regret theory as sensational reaction and investing in stock that everyone else is investing in, such an investor after noticing cognitive psychology errors refused to sell the stock for fear of capital loss after the stock shed prices. Investors, according to Alquraan et al. (2016), remained pessimistic when the stock market is bearish; few investors who could buy against the odds profit in the market; investors are confident when the market is bullish. Investors who buy stocks without cognitive bias and over-reaction to bad news stand a chance of profiting in the stock market.

Bad news, according to Ndwiga (2014), positively influenced stock prices and returns in the Nairobi stock market. This was also corroborated by Ali and Afzal in India where it was recognized that stock prices were bearish (low prices) during the time of financial crises. Alberg and Seckler (2016) 
also asserted that investors should invest in the stock markets by buying lowly priced stocks, however, Lakonishok et al. (1994) prescribed that investors should develop investment life cycle to buy stock with low prices, however the investors should be aware that growth stock according to Miwa and Ueda (2014), in the Japan and United States equity market is influenced by sentiments and behavior of investors. Otuteye and Siddiquee's (2015a, 2015b ) heuristic model inferred that growth stocks were prone to cognitive errors, however, Francis et al. (2000) submitted that abnormal earnings and over-reaction by investors generally determined stock prices in the equity market. However, Barberis, Mukherjee and Wang (2016) revealed that investors tended to be pessimistic to buy the value stocks. Bird and Casavecchia (2007) displayed bias on the value stocks, they believed that value stocks are more vulnerable to negative shocks in the economy than the growth stocks; consequently, wealthy investors, according to Cronquvist et al. (2013, 2015), preferred the growth stocks to the value stocks. Similarly, Gulen et al. (2011) affirmed that the value stocks respond more to the general economy than the growth stocks. Fernández (2007) and Fernández (2009) from the University of Navarra reported the cognitive bias and the irrationality of the investors in the equity market. Furthermore, Fama and French $(1995,1998)$ revealed irrational behavior on stock prices on the Japan Stock Exchange (JSE), ih the US stock market and most other developed stock market. This is further affirmed in Hotchkiss and Strickland (2000) and Glushkov (2007) that institutional bias influenced stock prices and the value stocks had lower sentiments than the growth stocks.

Alquraan et al. (2016) recognized that behavioral factors (over-confidence, loss averse and perception of investors' risk) significantly affected decision of the investors in the stock market. Mahina et al. (2017) confirmed that there is a positive linear relationship between over-optimism bias and stock investment, investors suffer behavioral biases in the Rwanda Stock Market. Metwally and Darwish (2015) reveal significant evidence that overconfidence, self-attribution and investors' confidence ignited the momentum when the Egypt Stock Market demonstrates an upward trend. Babajide and Adetiloye (2012), while inves- tigation the Nigeria Stock Exchange (NSE), provide strong evidence that the behavioral bias exists, but there are weak negative behavioral biases and performance in the stock market.

\section{METHODOLOGY}

The study was undertaken with primary survey premised on the data sourced from 1,000 copies of questionnaire randomly distributed to the investors in the Nigerian equity market, Lagos. The population of the study consisted of the individual and institutional investors in the country. The respondents consisted of the individual investors, the foreign investors and researchers that were met at the Lagos Stock Market. The institutional investors include the Pension Fund Managers, Unit Trusts, Banks, Insurance, Stock Brokers, Securities and Exchange Commission (SEC) and other institutional agencies. The basis for selection of 1,000 respondents to the questionnaire were the number of deals per day, the volume of transactions per day, the daily patronage in the market, stock brokers' activities, the regulatory agencies and the institutional investors in the market. The number of deals per day was above 4,000 as at 2017 , thus 1,000 copies of questionnaire represented about $25 \%$ of the deals per day in the Nigerian Stock Market (NSE, 2017). The copies of the questionnaire were distributed using the cluster sampling techniques randomly to the classes of the respondents, because the investors are assumed to be rational with the same objective of returns maximization and risk minimization given the choice of the growth and value stocks on the Nigeria Stock Exchange (NSE).

The perceptions of rational investors whether individual or institutional are the same, the objective is to maximize returns and minimize risk; therefore, the same copies of the questionnaire was given to all the respondents used for the study, and institutional investors in the Nigerian stock market and only 879 copies of the questionnaire were fully filled and returned. The copies of the questionnaire were constructed from the results of the empirical work by Zakaria and Hashim (2017), Subash (2012), and Fama and French (1995, 1998). The cluster sampling technique is suitable, because the determination of the total population 
of the investors (individual and institutional) in the Nigerian stock market was not feasible. It may be controversial to use either the volume of the transactions or the number of deals as a proxy of the total population of the investors in the market (Afonja et al., 2014).

That was because there were many individual investors who invested in stocks by going indirectly through other investors; also, they may go through the institutional investors or through surrogates. Therefore, it may be misleading and debatable to use either the volume of transactions or the number of deals as the total population of the investors on the Nigeria Stock Exchange. The study could have chosen the stratification sampling technique instead of the cluster sampling adopted in the study. The stratification sampling technique is only appropriate when the total population of the investors is precise on the Nigeria Stock Exchange (NSE). The total population of the investors was in clusters and not precise, they were in more than one group, which could not easily be determined. According to Afonja et al. (2014), a two-stage cluster sampling is suitable where the study of every unit in a cluster is not feasible to be investigated separately. Therefore, a random sample of the units was taken in each cluster for investigation.

Descriptive statistics and Multinomial Logistic Regression (MLR) analyses were adopted to measure the relationship between the response variable and the set of explanatory variables. This was engaged to fit a logistic regression model of an observed proportion. If investors entered the Nigeria Stock Exchange (NSE), some would buy stocks while some will not; Multinomial Logistic Regression (MLR) was used to measure the behavior of the various investors as they entered and exited the Nigerian stock market. MLR was engaged in the study, because the dependent variables (growth stocks, value stocks and investors who were indifferent) were more than two variables, thus it is the most appropriate model. The copies of questionnaire were administered to measure the activities of the Pension Fund Managers, the assets managers, the stock brokers, the shareholders, institutional investors and individual investors on Stock Choice (SC) of the growth and value stocks on the floor of NSE (Fitzgerald \& Leblanc, 2000). The MLR was adopted to analyze copies of ques- tionnaire administered to the respondents with a view to draw inferences as to whether cognitive psychology, representative and mental biases significantly influenced the choice of the growth or the value stocks on the Nigeria Stock Exchange (NSE).

The sets of equations below reported the tests that were conducted in the study. The Wald test was used to evaluate the significance level of individual MLR of the model. Equation (1) in the model specification below evaluated statistical test of significance for individual logistic regression coefficient, it was examined through the Wald test. The MLR used three goodness of fit tests to evaluate $\mathrm{R}^{2}$, which is the coefficient of determination; it explains whether the explanatory variables significantly explain the explained variable. In the study, these were also described in equations (2) to (4) as the Cox and Snell, Nalgekerke, Mc Fadden and Hosmer and Lemeshows' Chi square test and measured the goodness of fit of the model. The Cox and Snell's were measured by engaging the log probaility of occurrences. In order to achieve a threshold of $0-1$, Nagelkerke's $\mathrm{R}^{2}$ was used to divide Cox and Snell's $\mathrm{R}^{2}$ using the maximum value to evaluate the variability in Stock Choice (SC) that could be predicted with the explanatory variables. The Mc Fadden's $\mathrm{R}^{2}$ was engaged to determine the lower common pseudo - $\mathrm{R}^{2}$ variant, this was based on the log-likelihood kernels of the whole values versus the intercept only, this was evaluated to determine the coefficient of the model variation; it is similar to R-square in the normal regression analysis.

\section{MODEL SPECIFICATIONS}

$$
\begin{aligned}
& Z=W=\frac{\beta_{i}}{\sigma \beta_{i}}, \\
& R_{M C F}^{2}=1-\frac{L_{n}\left(L_{m}\right)}{L_{n}\left(L_{0}\right)} .
\end{aligned}
$$

The COX and Snell $R^{2}$ are:

$$
R_{C \&^{1} s}^{2}=1-\frac{L_{0}}{L_{m}}
$$




$$
\begin{aligned}
& H=\sum_{g=1}^{G}\left(\frac{\left(O_{1 g}-E_{1 g}\right)^{2}}{E_{1 g}}+\frac{\left(O_{0 g}-E_{0 g}\right)^{2}}{E_{0 g}}\right)= \\
& =\sum_{g=1}^{G} \frac{\left(O_{1 g}-E_{1 g}\right)^{2}}{N_{g} \pi_{g}\left(1-\pi_{g}\right)},
\end{aligned}
$$

where $O=$ observed, $E=$ expected, $O_{1 g}, E_{1 g}, O_{0 g}, E_{0 g}, N_{g}, \pi_{g}$ represent the observed events, $Y=1$; expected events $Y=1$; observed events $Y=0$; expected events $Y=0$.

Total observation is the predicted risk of the growth risk decile group; and $G$ is the number of groups in the study, these are three, the growth stocks, the value stocks and indifference investors on the growth and value stocks classification in the Nigerian equity market. The test statistics asymptotically follows an $X^{2}$ administration of G-2 degrees of freedom. In the study, the response variables were represented from the responses that were obtained from the 879 copies of the fully filled questionnaire (87.9\%) that were returned. There were no missing values from the copies of questionnaire returned by the respondents. These responses were divided into endogenous and exogenous factors. The copies of the questionnaire were administered to educated investors in the Nigeria Stock Exchange (NSE), Lagos. Thus, the model of the study is hypothetically structured as:

$$
\begin{aligned}
& \ln \left(\frac{\operatorname{Pr}\left(S_{c}=\text { ValueStock }\right)}{\operatorname{Pr}\left(S_{c}=\text { GrowthStock }\right)}\right)= \\
& =\beta_{o}+\beta_{1} G S F+\beta_{2} \text { VSRU }+\beta_{3} G S S T V S+ \\
& +\beta_{4} P G S T V+\beta_{5} \text { DPIG }+\beta_{6} S E B F G+ \\
& +\beta_{7} P E R a+\beta_{8} I P P F Y+\beta_{9} G S H H P+ \\
& +\beta_{10} G S O V+\beta_{11} \text { LPSS }+\varepsilon,
\end{aligned}
$$

$$
\begin{aligned}
& \ln \left(\frac{\operatorname{Pr}\left(S_{c}=\text { Undecided }\right)}{\operatorname{Pr}\left(S_{c}=\text { GrowthStock }\right)}\right)= \\
& =\beta_{o}+\beta_{1} G S F+\beta_{2} V S R U+\beta_{3} G S S T V S+ \\
& +\beta_{4} P G S T V+\beta_{5} \text { DPIG }+\beta_{6} S E B F G+ \\
& +\beta_{7} P E R a+\beta_{8} I P P F Y+\beta_{9} G S H H P+ \\
& +\beta_{10} G S O V+\beta_{11} L P S S+\varepsilon,
\end{aligned}
$$
rameters from the research questions that represented the predictor variables from the questionnaires to be administered.

\section{DATA PRESENTATION, ANALYSES AND DISCUSSIONS OF RESULTS}

The survey results were analyzed using SPSS 20 statistical package. Frequency distributions, mean, standard deviation, inferential analyses and reliability tests were deduced based on the reaction of the respondents for each question on the copies of the questionnaire administered on the demographic information, occupational, educational and cognitive psychology bias factors influencing the choice of either the growth portfolio or the value portfolio. The results of the survey represented $87.9 \%$ fully filled and returned questionnaires that were returned by the respondents.

\subsection{Demography and profile of respondents}

Tables 1A to 3A (see Appendix A) give the demographic and social economic profiles of the respondents. In Table 1A, 461 (52.4\%) respondents were female and the remaining respondents were male 418 (47.6\%) of 879 respondents that returned their copies of the questionnaire. This suggests that female dominated investment in the Nigerian stock market. It means that the proportion of investment in the market by female is higher than male investment. Also, Table $2 \mathrm{~A}$ reveals that majority of the respondents, 456 (51.9\%), were between the ages of $41-50$ years and 275 (31.3\%) range in 3140 years. The Table indicated that few of them, 13 $(1.5 \%)$ and $2(0.2 \%)$, are of ages $51-60$ years and above 60 years and only 133 (15.1\%) of them are between the age of 18-30 years. This supports that most of the respondents were within the working age and others fall within the dependency ratio. Also, out of 879 respondents in Table $3 \mathrm{~A}$, only $245(27.9 \%)$ were single, while $634(72.1 \%)$ were married. This indicates that married investors were more than the single investors, perhaps the stock investments were made to meet future family commitments. Table $1 \mathrm{~B}$ reported in Appendix 
$\mathrm{B}$ denotes that 28 (3.2\%) respondents were stock brokers, 54 (6.1\%) were investment bankers, 124 (14.1\%) were pension fund managers, 154 (17.5\%) were individual investors, 497 (56.5\%) were money managers and the remaining respondents belong to other group(s).

Table 1B shows that the market was dominated by institutional investors; they made institutional investment and also invested on behalf of the individual investors. Cronqvist et al. (2015), Moskowitz (2010), Hirschey and Nofsinger (2008), Hotchkiss and Skrickland (2000), Chan and Lakonishok (2004), Fama and French $(1995,1998)$ corroborated this evidence, that is in the advanced and the rapidly growing equity markets, institutional and wealthy investors demonstrated more cognitive biases for the growth stocks, (Hirschey \& Nofsinger 2008). In the study, institutional investors were the stock brokers, pension fund administrators, money managers, banks and insurance companies among other institutional investors on the NSE.

Table 2B in Appendix B shows that bulk of the respondents were B.Sc. holders; that is $349(39.7 \%)$, 343 (39\%) possessed Higher National Diploma, 95 (10.8) were Masters in Science or Business Administration, 61 (6.9\%) had National Diploma; 13 (1.5\%) were doctorate degree holders, while the remaining respondents were either holders of West African School Certificate or others. On professional qualification, it is observed (Table 3B in Appendix B) that 288 (32.8\%) were holders of FCIS/ACI, 204 (23.2\%) held FCIB/ACIB, 163 (18.5\%) belonged to FCA/CA, and other respondents did not have any professional membership or they belonged to other professional bodies that were not captured in the questionnaire. Table $4 \mathrm{~B}$ reveals the cadre of the respondents that filled the questionnaire. $72(8.2 \%)$ respondents were in a junior category, $732(83.3 \%)$ in a middle category and the remaining 75 (8.5\%) belonged to a senior category. From Tables 3B to 4B, it appears that the respondents were knowledgeable about the stocks that were quoted on the NSE floor. The stock market, according to Helo (2013) is a knowledge based market, the educational and professional qualifications reported in Tables $1 \mathrm{~B}$ to $4 \mathrm{~B}$ give credence to the claim that majority of the investors have knowledge of the operations in the Nigerian stock market.

\subsection{Empirical analyses and discussion of results}

Table 1C reported in Appendix C reveals the average, deviation from average and variance of factors of the growth and the value stocks cognitive psychology bias construct. In Table 1C, the mean value of 5.77 of investors who demonstrated strong mental bias in favor of the growth stocks irrespective of fall in earnings is high; similarly, the mean value of 6.45 showed that growth stocks were superior to value stocks. In the same vein, irrespective of the degree of the financial fundamentals, institutional investors always preferred the growth stocks to the value stocks, this is because the mean value of 6.24 for the growth stock was greater than the mean value of 5.09 for the value stocks. Also, when performance of the large cap stocks (i.e., growth stocks) dropped and performance of the value stocks (small cap stocks) rose, sentiments and irrational behavior favored the large cap stocks, because the mean value of 5.48 is greater than the mean value of 4.28 for the small cap stocks. It means even if there is a drop in the financial fundamentals of the large cap stocks (i.e., growth stocks) in relation to the value stocks (small cap stocks), the investors in the Nigerian stock market still preferred the growth stocks to the value stocks. Furthermore, on the average, the mean value of 6.38 for equity investors that showed enthusiasms and trust in growth stocks is greater than the average value of 4.12 for investors who wanted the value stocks. This supports the existence of cognitive psychology bias in favor of the growth stocks.

At the same time, with increase or decrease in the financial fundamentals, investors appear to believe that the growth stock $\geq$ value stock and it cannot be less, because the mean value of 6.38 for the former is better than the mean value of 4.60 for the latter. It means that a fall in the performance indices of growth stocks did not perturb the investors on the NSE to prefer the growth stocks. This in a nutshell means that the growth stocks have lower odd and the high likelihood of occurrence on the NSE. Also, at the time of economic trough, the bias favors the growth stocks on the average because the mean value of 6.06 is 1.36 times greater than the mean value of 4.45 for the value stocks. The case was not different, the momentum 
favors growth stock in the bear and the bull market, this is because the mean value of the growth stocks $(6.23,6.13)$ was greater than that of the value stocks $(4.54,5.65)$; the descriptive statistics in table $1 \mathrm{C}$ gives credence to the existence of the cognitive psychology bias in favor of the growth stocks on the NSE.

The goodness-of-fit table in Table $2 \mathrm{C}$ displays two tests of the null hypothesis, which means that the MLR model adequately fits the data. From Table 2C one can see that, the level of significance for both Pearson and Deviance is greater than the 0.05 confidence interval, this suggests that the MLR model fits the data adequately. This is because 1.0 for the Pearson and 0.96 for the deviance are above the 0.05 significance level. Thus, the primary data obtained are consistent with the model assumptions. Thus, the null hypothesis $(\mathrm{Ho})$ is accepted.

In Table 3C displays the results of the likelihood ratio. It reveals the final MLR model in comparison with the model in which all the parameters are not captured. In the table, the chi-square statistic gives information about the difference between the -2 log-likelihoods of the models without parameters, which are the models for variables that were excluded from the questionnaire and models with parameters, models that were captured from the questionnaire administered in the study. The 0.000 level of significance in Table $3 \mathrm{C}$ is less than 0.05 . This in a nutshell signifies that the model with the parameters captured from the questionnaire is better than that without parameters, the variables that were not included in the analyses. In other words, it can be inferred that the included factors from the copies of the questionnaire administered are better than the excluded factors. Consequently, it could be inferred that the included factors in the model explain significantly the influence of cognitive psychology bias on the choice of stocks on the NSE. This validates the earlier empirical study by Babajide and Adetiloye (2012) on the existence of behavioral biases on the NSE, Vu (2012) and Miwa and Ueda (2014) among others who recognized that there were mental biases in favor of the growth stocks instead of the value stocks in the developed and emerging stock markets.

Table 4C reported the Pseudo R-square table. The Cox and Snell's $\mathrm{R}^{2}$ is based on the log likelihood for the model compared to the log likelihood for a baseline model. The categorical outcome has a theoretical maximum value of less than 1 , which means that the MLR model is efficient. The Nagelkerke's $\mathrm{R}^{2}$ in Table $4 \mathrm{C}$ refers to an adjusted version of the Cox \& Snell R-square. It adjusts the scale of the statistic to cover the full range from 0 to 1 . The McFadden's $\mathrm{R}^{2}$ is another method of adjusted $\mathrm{R}^{2}$, it is based on the log-likelihood kernels of the intercept related model and the full estimated model. In Table 4C, the result from Nagelkerke test suggests that about $29.8 \%$ variation in the choice of stock procured on the NSE was influenced by cognitive psychology bias. This is consistent to the empirical evidence from Miwa and Ueda (2014), Hotchkiss and Strickland (2000), Glushkov (2007), Gilli and Schumann (2009).

The likelihood ratio tests in Table 5C diagnoses the benefits of each variable to the model. For each effect, the -2 log-likelihood was derived for the reduced model. A reduced model signifies a model without the effect; these denote variables that were excluded in the study. In Table 5C, the chi-square statistic measures the differential of the $-2 \log$-likelihoods of the prototype model (i.e., the reduced model) and the final model that was reported in the model fitting information table in Table 3C. If the level of significance of the test is less than 0.05 , it implies that the identified factors have effect and they contribute to the model. In Table 5C, the cognitive psychological bias variables (e.g., Growth Stocks are Famous (GSF), overpriced, highly demanded Growth Stocks and Value Stocks Relatively Unknown (VSRU), lowly priced, unestablished, and lowly demanded stocks by the investors) significantly influence the choice of stock on the Nigeria Stock Exchange (NSE). Thus, an increase in the demand for growth stocks exerts a corresponding decrease in the demand for value stocks. Similarly, a small drop in the performance indices of growth portfolio did not encourage investors on the Nigeria Stock Exchange to buy value stocks even when there was an increase in the performance fundamentals of the value stocks. All these factors have their significance values less than 0.05 .

The study's null Hypothesis is to recognize whether Cognitive Psychology Bias does not exert influence on the choice of either the growth port- 
folio or the value portfolio in the Nigerian Stock Market. The hypothesis measures whether mental accounting bias, representative and institutional biases, emotional sensational sentiments affect the choice of either the growth or value portfolios using Multinomial Logistic Regression (MLR). The results of the MLR are reported in Table 6C, where GSF denotes growth stocks are famous, IP represents the investor preference during the bear market, VSRU represents the value stocks, which were relatively unknown, and DPIG represents drop in the performance indices of growth stocks. The table gives information about the parameters of the MLR model. Table 6C is the estimated MLR coefficients of the models. An important feature of the MLR model in the study is that it estimated two models. In the study, the growth stock was indicated as the referenced group; therefore, the value stock was defined in relation to the growth stock and a model for undecided relative to the growth stock. Therefore, since the parameter estimates are relative to the referenced group, the standard interpretation of the MLR is that for a unit change in the explained variable there is a corresponding change in the explanatory variables. The empirical models are reported in equations (7) to (8):

$$
\begin{aligned}
& \ln \left(\frac{\operatorname{Pr}(S c=\text { ValueStock })}{\operatorname{Pr}(S c=\text { GrowthStock })}\right)= \\
& =20.417-1.197 \cdot G S F-0.548 \cdot I P+\varepsilon,
\end{aligned}
$$

$\ln \left(\frac{\operatorname{Pr}(S c=\text { Undecided })}{\operatorname{Pr}(S c=\text { GrowthStock })}\right)=$

$=0.929+2.084 \cdot V S R U-1.719 \cdot D R I G+\varepsilon$.

In table 6C, the standard error for GSF (Growth Stock is Famous) is 0.294 with Wald test value of 16.5 , exponential value is 0.302 and the significance value is 0.000 ; this implies that popularity of growth stock is significant. Hence, the alternative hypothesis is accepted, that is, growth stock is famous, which means that the choice of the growth stock significantly influenced the choice of the value stocks inversely related to the investor on the NSE. This is consistent with the assertion of Cronquvis et al. $(2013,2015)$ that wealthy investors preferred growth stocks (famous stocks). Moreover, for investors' preference during the bear market, the standard error is 0.217 , Wald test value is 6.361, and exponential value is 0.578 , the significance value is 0.012 . Investors' preferences during the bear market also significantly affect the choice of the growth stock by investors.

From equations (7) and (8) it can be seen that the MLR model is defined to evaluate the choice and relationship of the value stock in relation to the growth stock. From the models, a unit increase in the popularity of low odds growth stock results in corresponding reduction of 1.197 in the relative high odds of investing in the value stock. Also, a unit increase in investors' choice during the bear market for the low odds growth stock exerts a reduction of 0.548 comparatively to high odds of investing in the value stock. The relative odds for investing in the growth stock is lower (0.302) compared to investors' choice of higher odds value stock during the bear market (0.578) as reported in Table 6C. The lower odd implies greater likelihood of demand for the growth stocks and higher odds portends lower demand for the Value on the NSE.

In Table 6C, the standard error (SE) for the relatively unknown status of value stock (VSRU) is 0.905 with Wald test value of 5.300, exponential value, that is higher odd of value stock (VSRU) is 8.037 in relation to lower odd of drop in performance and corresponding increase in the demand for the growth stock (DPIG) of 0.179; and the significance value is 0.021; therefore, from this results it appears that the value stocks are relatively unknown, this relationship is significant with corresponding high demand for growth stock and low demand of the value stock. The greater odd of the value stock suggests lower likelihood of demand for the value stocks and lower odd of the growth stock implies higher demand for the growth stock on the NSE. Also, drops in the performance indices of the growth stock have standard error of 0.730 , Wald test value is 5.544, and exponential value is 0.179 with 0.019 significance value. Therefore, drops in the performance indices of the growth stock have significantly affected choice of the value stocks by the investors on the NSE. Hence, the alternative hypothesis is accepted, this in effect means that the value stock is relatively unknown with higher odds and lower demand and the growth stock with lower odd and higher demand on the NSE. The relationship is inverse and significant. The evidence is supported by the assertions of Cronqvist et al. (2013) and Ndwiga (2014). 
From equation 3.8, this model compares the choice of unknown investors to the growth portfolio. Here, unknown investors refer to investors that could not distinguish between the value stock and growth stock. These sets of investors just invest in a particular stock without adequate knowledge of such stock. This is consistent to the claim of Helo (2013), on the New York Stock Exchange (NSE). Helo (2013) asserted that many investors lack knowledge to profit from the Stock Market. The model indicates that a unit decrease $(-1.197)$ in the demand for the unpopular value stock is connected with a comparative rise in the demand for the lower odd growth and well-established the growth stock in the Nigerian equity market. Also in Table 6C (parameter estimate), a drop in the performance indices of the growth stocks (DPIG) results with a rise in the performance of a value stock give a corresponding 1.719 decrease in the likelihood of demand for value stock (i.e., un- popular stocks, high odd stocks). The relative risk ratio for investing in unknown value stock is very high (8.037) compared to investing in the growth stock with small drop in the performance indices (0.179) as seen in Table 6C.

The classification of the model is reported in Table 7C. It indicates the practical results of using the MLR model. For each case, the predicted reaction of each group is considered before choosing the group with anticipated highest probability. Of the cases used to create the model, 85 out of 272 people who preferred growth stocks were classified correctly, 141 out of 274 people who chose value stock were classified correctly, and 87 out of 233 people who were undecided were classified correctly. On the average, $52.7 \%$ of the cases were classified correctly. The result of the reliability test reported in Table 2D signifies the Cronbach's Alpha value of 0.734 , which is greater than 0.6 , which portends that the data is reliable.

\section{CONCLUSION AND RECOMMENDATIONS}

The paper provides strong evidence of cognitive psychology bias in favor of the growth stock on the Nigeria Stock Exchange. From Table 6C reported previously, the standard error that growth portfolio is popular among the investors is 0.294 with Wald statistics of 16.5 , exponential value is 0.302 and the degree of significance is 0.000 . This suggests that high demand and popularity of growth stocks are significant. Hence, the alternative hypothesis is accepted, which means that, with drop in performance of the growth stock, there is an increase in the demand for the growth stocks with a significant corresponding decrease in the demand for the value stocks by the investors in the Nigerian equity market. This is consistent with the biases and sentiments that exist in the developed and the emerging stock markets. Also, for investors' preference during the bear market, the standard error is 0.217 , Wald test value is 6.361 , and exponential value is 0.578 , the significance value is 0.012 . This implies that the investors' preferences for the growth stocks during the bear market also significantly affect choice of the value stocks; this in a nutshell denotes that investors demonstrate enthusiasms and prefer to choose more of the growth stocks than the value stocks irrespective of the drop in the performance indices of the growth stocks.

\section{RECOMMENDATIONS}

The following recommendations are made in the study:

a) Investors should be aware of consequence sentiments and unnecessary emotion in constructing return-driven stock portfolio; consequently, they should reduce representation, institution and personal biases in favor of the growth stocks in the Nigerian stock market.

b) This study confirms the existence of Cognitive Psychology Bias in favor of the growth stocks in the Nigerian stock market. Investors should avert sentiments by listening to the advice of stock brokers to make choice of stocks without bias. 
c) Therefore, the stock market practitioners are advised to be keenly interested in the use of scientific approaches by choosing stocks based on performance rather than using rule of thumb to buy or not to buy a particular stock.

d) Portfolio managers should evolve a scientific approach to choose return-driven growth and value portfolio without unnecessarily favoring either of the stock classifications.

\section{REFERENCES}

1. Afonja, B., Olubusoye, O. E., Ossai, E., \& Arinola, J. (2014). Introductory Statistics. A Learner's Motivated Approach. Ibadan: Evans Brothers (Nigeria Publishers) limited.

2. AFR INVEST (2018). The Nigerian Economy and Financial Markets Review and 2018 Outlook. Retrieved from https://www.afrinvest.com/ wp-content/uploads/2018/01/ Nigerian-Economy-and-Financial-Market-2017-Review2018-Outlook-The-VirtuousCycle\%E2\%80\%A6Again.pdf on (accessed on August 20, 2018).

3. Ailemen, Ikpefan O., Akhanolu, I. A., \& Chibuzor, O. T. (2016). Deregulation of Foreign Exchange Market and its Effect on Industrial Produce in Nigeria. Asian Journal of Information Technology, 15(13), 2101-2107.

4. Alberg, J., \& Seckler, M. (2016). Now is the Time for Value to Outperform Growth. Advisor Perspective, 1-9. Retrieved from https://www.advisorperspectives. com/articles/2016/02/01/now-isthe-time-for-value-to-outperformgrowth

5. Alquraan, T., Alqisie, A., \& Al Shorafa, A. (2016). Do Behavioral Factors Influence Stock Investment Decisions of Individual Investors? (Evidence from Saudi Arabia). American International Journal of Contemporary Research, 6(3), 159-169.

6. Antunovich, P., \& Laster, D. S. (1999). Do Investors Mistake a Good Company for a Good Investment? Federal Reserve Bank of New York (Staff Reports, No. 60.), 1-39.

7. Babajide, A. A., \& Adetiloye, K. A. (2012). Investors' Behavioral
Biases and the Security Market: An Empirical Study of the Nigerian Security Market. Accounting and Finance Research, 1(1), 219-229.

8. Barberis, N., Mukherjee, A., \& Wang, B. (2016). Prospect Theory and Stock Returns. The Review of Financial Studies, 29(11), 30683107. https://doi.org/10.1093/rfs/ hhw049

9. Bird, R., \& Casavecchia, L. (2007). Value Enhancement Using Momentum Indicators: The European Experience. International Journal of Managerial Finance, 3(3), 229-262. https://doi. org/10.1108/17439130710756907

10. Buffet, W. (1984). The Superinvestors of Graham-andDoddsville. Hermes, Columbia Business School. Retrieved from https://www8.gsb.columbia.edu/ sites/valueinvesting/files/files/Buffett1984.pdf

11. Chan, L. K. C., \& Lakonishok, J. (2004). Value and Growth investing: Review and Update. Financial Analysts Journal, 60(1), 71-85.

12. Cronqvist, H., Siegel, S., \& Yu, F. (2013). Value versus growth investing: Why do different investors have different styles? Journal of Financial Economics, 117(2), 333-349. https://doi. org/10.1016/j.jfineco.2015.04.006

13. Elan, Seth, L. (2010). Behavioral Patterns and Pitfalls of U.S. Investors (A Report of the Federal Research Division). Washington: Library of Congress. Retrieved from http://www.loc.gov/rr/frd/ pdf-files/SEC_Investor-Behavior. pdf

14. Faerber, E. (2000). All About Stocks. The Easy Way to Get Started. Everything You Need to Know
About Stocks (p. 77). United States: McGraw Hill Companies.

15. Fama, E., \& French, K. (1995). Size and Book-to-Market Factors in Earnings and Returns. Journal of Finance, 50(1), 131-156. https:// doi.org/10.1111/j.1540-6261.1995. tb05169.x

16. Fama, E., \& French, K. (1998). Value versus Growth: The International Evidence. The Journal of Finance, 53(6), 19751999.

17. Fernández, P. (2007). Company Valuation Methods. The Most Common Errors in Valuations (IESE Working Paper No. 449). IESE Business School, University of Navarra.

18. Fernández, P. (2009). Beta Used by Professors: A Survey of 2500 Answers (IESE Working Paper No. 822). IESE Business School, University of Navarra. Retrieved from https://www.iese.edu/research/pdfs/di-0822-e.pdf

19. Fitzgerald, S., \& Leblanc, M. (2000). Research Design and Methodology Section: Logistic regression for School Psychologists. School Psychology Quarterly, 15(3), 344-358

20. Francis, J., Olsson P., \& Oswald, D. R. (2000). Comparing the Accuracy and Explainability of Dividend, Free Cash Flow and Abnormal Earnings Equity Value Estimates. Journal of Accounting Research, 38(1), 45-70. https://doi. org/10.2307/2672922

21. Gilli, M., \& Schumann, E. (2009). Risk-Reward Optimization for LongRun Investors: an Empirical Analysis. Paper presented at the AFIR/ LIFE Colloquium 2009 in Munich. Retrieved from https://www.actuar- 
ies.org/Munich2009/papers/AFIR/ Fri_11.30_AFIR_Schumann_Portfolio_risk_Paper.pdf

22. Glushkov, D. (2007). Sentiment Beta. University of Pennsylvania, the Wharton School. http://dx.doi. org/10.2139/ssrn.862444

23. Graham, B., \& Dodd, D. L. (1934). Security Analysis. New York: McGraw-Hill Companies, Inc.

24. Gulen, H., Xing Y., \& Zhang, L. (2011). Value versus Growth: Time-varying Expected Stock Returns. Financial Management, 40(2), 381-407. https://doi.org/10.1111/j.1755053X.2011.01146.x

25. Helo, E. M. (2013). The Modern Intelligent Investor: Can value and Growth Investing Strategies Evolve to Maximum Returns and Reduce Risk (Master of Business Administration Thesis). University of Bath, Beneficiaro Colfuturo.

26. Hirschey, M., \& Nofsinger, J. (2008). Investments Analysis and Behavior (pp. 89-389). New York: McGraw-Hill Irwin.

27. Hotchkiss, E. S., \& Strickland, D. (2000). Does Shareholder Composition Affect Stock Returns? Evidence from Corporate Earnings Announcements. Seminars at University of Minnesota. Retrieved from http://wwwl.american.edu/ academic.depts/ksb/finance_realestate/mrobe/Seminar/Strickland.pdf

28. Isibor, A., Ojo, J., Ikpefan, O. A. (2018). Does financial deregulation spurs economic development in Nigeria? Journal of Applied Economics Sciences, 12(8), 2339-2350.

29. Isibor, A. A., Ikpefan, O. A., Okafor, T. C., Ojeka, S. (2016). Impact of money market on the liquidity of some selected quoted banks in Nigeria. International Business Management, 10(5), 646-665.

30. Jones, C. P. (2010). Investments, Principles and Concepts (pp. 1-34). Australia: John Wiley \& Sons (Asia) limited.

31. Kyröläinen, P. (2007). Essays on Investors Behavior and Trading Activity (Dissertation of Acta Universitatis Oulvensis). Retrieved from http://jultika.oulu.fi/files/ isbn9789514284366.pdf

32. Lakonishok, J., Shleifer, A., \& Vishny, R. (1994). Contrarian Investment, Extrapolation and Risk. Journal of Finance, 49(5), 1541-1578. https://doi. org/10.1111/j.1540-6261.1994 tb04772.x

33. Mahina, J. N., Muturi, W. M., \& Memba, F. S. (2017). Effect of Over-Optimism on Investments at the Rwanda Stock Exchange. International Journal of Management and Commerce Innovations, 5(1), 169-181.

34. Metwally, A. H., \& Darwish, O. (2015). Evidence of the OverConfidence Bias in the Egyptian Stock Market in Different Market States. The Business Management Reviews, 6(4), 178-198.

35. Miwa, K., \& Ueda, K. (2014). Analyst Preference for Growth Investing and Vulnerability to Market-Wide Sentiments. The Quarterly Review of Economics and Finance, 61, 40-52. https://doi. org/10.1016/j.qref.2015.11.003

36. Moskowitz, T. J. (2010). Momentum Investment Finally Accessible for Individual Investors. Investment Management Consultants Association, 22-26. Retrieved from https://business. nasdaq.com/media/Momentum Investing_Tobias_J_Moskowitz_ PhD_Investments_Wealth_Monitor_IMCA_tcm5044-42319.pdf

37. Ndwiga, M. D. (2014). Dynamics of Conditional Stock Returns: An Empirical Analysis of the Nairobi Securities Exchange Limited for the period 2001-2014 (Thesis of master of Art in Economics), University of Nairobi. Retrieved from http:// erepository.uonbi.ac.ke/bitstream/ handle/11295/76282/Ndwiga_\%20 Dynamics\%20of\%20Conditional\%20Stock\%20Returns\%20Volatility.pdf? sequence $=4$

38. NSE, E. (2017). Fact Book of the Nigeria Stock Exchange. Retrieved from contact@nse.com.ng (accessed on April 29, 2018)

39. Ogunbanjo, A. (2018). The Nigerian Stock Exchange (NSE) Annual Reports. Retrieved from www.nse.com.ng (accessed on August 20, 2018)
40. Okwu, A. T. (2015). ICT Adoption and Financial Markets: A Study of Leading Stock Market in Africa. Journal of Accounting and Management, 53-76. Retrieved from https://hrcak.srce.hr/ file/226144 on 20 August, 2018.

41. Oladejii, T. F., Ikpefan, O. A., and Alege, P. O. (2018). Stock Market Volatility and NonMacroeconomic Factors: A Vector Error Correction Approach. Journal of Applied Economics Sciences, 13(2), 303-315.

42. Olowe, A. (2008). Financial Management, Concepts, Financial System and Business Finance (pp.204-246). Lagos: Brierly Jones Nigeria Limited.

43. Otuteye, E., \& Siddiquee, M. (2015a). Avoiding Financially Distressed Companies Using a Value Investing Heuristic. Journal of Investing, 24(3), 73-99.

44. Otuteye, E., \& Siddiquee, M. (2015b). Overcoming Cognitive Biases: A Heuristic for Making Value Investing Decisions. Journal of Finance, 16(2), 140-149.

45. Pandey, I. M. (2006). Financial Management (pp. 70-517). New Delhi: UBS Publishers' Distributors Pvt. Ltd.

46. Subash, R. (2012). Role of Behavioral Finance in Portfolio Investment Decisions: Evidence from India (Master thesis of the Charles University in Prague).

47. Vorwerg, J. (2015). Value Vs Growth: Evidence from the German Stock Market ( $5^{\text {th }}$ IBA Bachelor Thesis Conference). The Netherlands University of Twente.

48. Vu, Joseph. (2012).

Macroeconomic Process and Regional Economics Management: Do Momentum Strategy Generate Profits in Emerging Markets? Journal of Economic Literature, 10(3), 9-21.

49. Zakaria, N., \& Hashim, F. (2017). Emerging Market: Evaluating Graham's Stock Selection Criteria on Portfolio Return in Saudi Arabia Stock Market. International Journal of Economics and Financial, $17(2), 453-459$. 


\section{APPENDIX A. DEMOGRAPHIC ANALYSIS}

Table 1A. Gender

Source: Field survey (2017).

\begin{tabular}{|c|c|c|c|c|c|}
\hline \multicolumn{2}{|c|}{ Description } & $\mathbf{F}$ & $\%$ & Valid, \% & Cum, \% \\
\hline \multirow{3}{*}{ Valid } & Male & 418 & 47.6 & 47.6 & 47.6 \\
\hline & Female & 461 & 52.4 & 52.4 & 100.0 \\
\hline & Total & 879 & 100.0 & 100.0 & \\
\hline
\end{tabular}

Table 2A. Age

\begin{tabular}{|c|c|c|c|c|c|}
\hline & Description & $\mathbf{F}$ & $\%$ & Valid, \% & Cum, \% \\
\hline \multirow{6}{*}{ Valid } & $18-30$ years & 133 & 15.1 & 15.1 & 15.1 \\
\hline & $31-40$ years & 275 & 31.3 & 31.3 & 46.4 \\
\hline & $41-50$ years & 456 & 51.9 & 51.9 & 98.3 \\
\hline & $51-60$ years & 13 & 1.5 & 1.5 & 99.8 \\
\hline & 60 years above & 2 & .2 & .2 & 100.0 \\
\hline & Total & 879 & 100.0 & 100.0 & \\
\hline
\end{tabular}

Table 3A. Marital status

Source: Field survey (2017).

\begin{tabular}{|c|c|c|c|c|c|}
\hline \multicolumn{2}{|c|}{ Description } & \multirow{2}{*}{$\frac{\mathbf{F}}{245}$} & \multirow{2}{*}{$\begin{array}{c}\text { \% } \\
27.9\end{array}$} & \multirow{2}{*}{$\frac{\text { Valid, } \%}{27.9}$} & \multirow{2}{*}{$\frac{\text { Cum, \% }}{27.9}$} \\
\hline \multirow{3}{*}{ Valid } & Single & & & & \\
\hline & Married & 634 & 72.1 & 72.1 & 100.0 \\
\hline & Total & 879 & 100.0 & 100.0 & \\
\hline
\end{tabular}

\section{APPENDIX B. OCCUPATIONAL FINANCIAL AND EDUCATIONAL ANALYSES}

Table 1B. Occupational financial analysis

Source: Field survey (2017).

\begin{tabular}{|c|c|c|c|c|c|}
\hline & Description & $\mathbf{F}$ & $\%$ & Valid, \% & Cum, \% \\
\hline \multirow{7}{*}{ Valid } & Stock brokers & 28 & 3.2 & 3.2 & 3.2 \\
\hline & Investment banker & 54 & 6.1 & 6.1 & 9.3 \\
\hline & Pension fund manager & 124 & 14.1 & 14.1 & 23.4 \\
\hline & Investors & 154 & 17.5 & 17.5 & 41.0 \\
\hline & Money managers & 497 & 56.5 & 56.5 & 97.5 \\
\hline & Others & 22 & 2.5 & 2.5 & 100.0 \\
\hline & Total & 879 & 100.0 & 100.0 & \\
\hline
\end{tabular}

Table 2B. Highest qualification

Source: Field survey (2017).

\begin{tabular}{|c|c|c|c|c|c|}
\hline & Description & $\mathbf{F}$ & $\%$ & Valid, \% & Cum, \% \\
\hline \multirow{8}{*}{ Valid } & WASC & 5 & .6 & .6 & .6 \\
\hline & OND & 61 & 6.9 & 6.9 & 7.5 \\
\hline & HND & 343 & 39.0 & 39.0 & 46.5 \\
\hline & B.SC. & 349 & 39.7 & 39.7 & 86.2 \\
\hline & $M S c / M B A$ & 95 & 10.8 & 10.8 & 97.0 \\
\hline & Ph.D. & 13 & 1.5 & 1.5 & 98.5 \\
\hline & Others & 13 & 1.5 & 1.5 & 100.0 \\
\hline & Total & 879 & 100.0 & 100.0 & \\
\hline
\end{tabular}


Table 3B. Professional qualification

Source: Field survey (2017)

\begin{tabular}{|c|c|c|c|c|c|}
\hline & Description & $\mathbf{F}$ & $\%$ & Valid, \% & Cum, \% \\
\hline \multirow{5}{*}{ Valid } & $\mathrm{FCA} / \mathrm{CA}$ & 163 & 18.5 & 18.5 & 18.5 \\
\hline & $\mathrm{FCIB} / \mathrm{ACIB}$ & 204 & 23.2 & 23.2 & 41.8 \\
\hline & $\mathrm{FCIS} / \mathrm{ACIS}$ & 288 & 32.8 & 32.8 & 74.5 \\
\hline & Others & 224 & 25.5 & 25.5 & 100.0 \\
\hline & Total & 879 & 100.0 & 100.0 & \\
\hline
\end{tabular}

Table 4B. Level

Source: Field survey (2017).

\begin{tabular}{|c|c|c|c|c|c|}
\hline \multicolumn{2}{|c|}{ Description } & $\mathbf{F}$ & $\%$ & Valid, \% & Cum, \% \\
\hline \multirow{4}{*}{ Valid } & Junior & 72 & 8.2 & 8.2 & 8.2 \\
\hline & Middle & 732 & 83.3 & 83.3 & 91.5 \\
\hline & Senior & 75 & 8.5 & 8.5 & 100.0 \\
\hline & Total & 879 & 100.0 & 100.0 & \\
\hline
\end{tabular}

\section{APPENDIX C. DESCRIPTIVE AND INFERENTIAL ANALYSES}

\section{Table 1C. Descriptive statistics}

Source: Field survey (2017).

\begin{tabular}{|c|c|c|c|c|c|c|}
\hline Responses from the Respondents & $\begin{array}{c}\text { No } \\
\text { (Observ.) } \\
\end{array}$ & Min & Max & Mean & $\begin{array}{l}\text { Std. } \\
\text { dev. }\end{array}$ & Var. \\
\hline $\begin{array}{l}\text { You are aware of classification of stocks into Growth or value } \\
\text { stocks on the Nigerian Stock Exchange (NSE) }\end{array}$ & 879 & 1 & 7 & 6.42 & .910 & .829 \\
\hline $\begin{array}{l}\text { Stocks in the Nigeria Stock Market can be grouped into growth } \\
\text { stocks or value stocks }\end{array}$ & 879 & 1 & 7 & 6.37 & .991 & .982 \\
\hline $\begin{array}{l}\text { Usually, there are strong preferences and mental biases towards } \\
\text { growth stocks regardless of announcement of fall in earnings and } \\
\text { dividends payout ratio in the Nigeria Stock Market }\end{array}$ & 879 & 1 & 7 & 5.77 & 1.460 & 2.132 \\
\hline $\begin{array}{l}\text { Growth stocks are superior to value stocks because it always } \\
\text { guarantees higher returns on the Nigeria Stock Exchange (NSE) }\end{array}$ & 879 & 2 & 7 & 6.45 & .992 & .983 \\
\hline $\begin{array}{l}\text { In the past, irrespective of the increase or decrease in financial } \\
\text { ratios obtained from financial statements, individual and } \\
\text { institutional investors preferred growth stocks to value stocks in the } \\
\text { Nigerian Stock Market }\end{array}$ & 879 & 1 & 7 & 6.24 & 1.212 & 1.470 \\
\hline $\begin{array}{l}\text { In the past, irrespective of the increase or decrease in financial } \\
\text { ratios obtained from financial statements, individual and } \\
\text { institutional investors preferred value stocks to growth stocks in the } \\
\text { Nigerian Stock Market }\end{array}$ & 879 & 1 & 7 & 5.09 & 2.197 & 4.825 \\
\hline $\begin{array}{l}\text { Even if financial performance ratios obtained from annual reports } \\
\text { drop significantly in the past financial years, investors preferred } \\
\text { growth stocks to value stocks in the Nigeria Stock Market }\end{array}$ & 879 & 1 & 7 & 5.48 & 1.856 & 3.444 \\
\hline $\begin{array}{l}\text { In the past financial years, where financial performance of growth } \\
\text { stocks dropped slightly and the performance of value stocks were } \\
\text { on the high, investors switched their stock investments from growth } \\
\text { stocks to value stocks }\end{array}$ & 879 & 1 & 7 & 4.28 & 2.238 & 5.007 \\
\hline $\begin{array}{l}\text { From your experiences, a small drop in the performance indices of } \\
\text { growth stocks encouraged investors to buy value stocks as a result } \\
\text { of increased performance indices }\end{array}$ & 879 & 1 & 7 & 4.90 & 1.956 & 3.824 \\
\hline $\begin{array}{l}\text { Always, there are strong enthusiasm and belief in favor of growth } \\
\text { stocks }\end{array}$ & 879 & 1 & 7 & 6.38 & .780 & .608 \\
\hline $\begin{array}{l}\text { Always, there are strong enthusiasm and belief in favor of value } \\
\text { stocks }\end{array}$ & 879 & 1 & 7 & 4.12 & 1.182 & 1.398 \\
\hline $\begin{array}{l}\text { In the past, there was overreaction to slight increase or decrease } \\
\text { in the performance indices of growth stocks on the Nigeria Stock } \\
\text { Exchange }\end{array}$ & 879 & 1 & 7 & 6.38 & .812 & .659 \\
\hline $\begin{array}{l}\text { In the past, there was overreaction to slight increase or decrease } \\
\text { in the performance indices of value stocks on the Nigeria Stock } \\
\text { Exchange }\end{array}$ & 879 & 1 & 7 & 4.60 & .672 & .451 \\
\hline
\end{tabular}


Table 1C (cont.). Descriptive statistics

\begin{tabular}{|c|c|c|c|c|c|c|}
\hline Responses from the Respondents & $\begin{array}{c}\text { No } \\
\text { (Observ.) }\end{array}$ & Min & Max & Mean & $\begin{array}{l}\text { Std. } \\
\text { dev. }\end{array}$ & Var. \\
\hline $\begin{array}{l}\text { During economic recession, more preferences were given to } \\
\text { selection of growth stocks }\end{array}$ & 879 & 4 & 7 & 6.06 & .976 & .952 \\
\hline $\begin{array}{l}\text { During economic recession, more preferences were given to } \\
\text { selection of value stocks }\end{array}$ & 879 & 3 & 7 & 4.45 & .663 & .439 \\
\hline $\begin{array}{l}\text { In a bear market in the past financial years, investors preferred } \\
\text { growth stocks }\end{array}$ & 879 & 4 & 7 & 6.23 & .788 & .621 \\
\hline $\begin{array}{l}\text { In a bear market in the past financial years, investors preferred } \\
\text { value stocks }\end{array}$ & 879 & 3 & 7 & 4.54 & .663 & .440 \\
\hline $\begin{array}{l}\text { When the market was bullish in the past financial years, more } \\
\text { preferences were given to both growth stocks and value stocks on } \\
\text { the NSE }\end{array}$ & 879 & 1 & 7 & 5.44 & 1.280 & 1.639 \\
\hline $\begin{array}{l}\text { During the boom in the Nigeria Stock Market in the previous years, } \\
\text { more preferences and favor were given to growth stocks }\end{array}$ & 879 & 3 & 7 & 6.13 & .972 & .944 \\
\hline $\begin{array}{l}\text { During the boom in the Nigeria Stock Market in the previous years, } \\
\text { more preferences and favor were given to value stocks }\end{array}$ & 879 & 1 & 7 & 5.65 & 1.165 & 1.358 \\
\hline Valid N (list wise) & 879 & & & & & \\
\hline
\end{tabular}

Table 2C. Goodness-of-Fit

Source: Field survey (2017).

\begin{tabular}{l|c|c|c}
\hline \multicolumn{1}{c|}{ Description } & Chi-square & Df & Sig. \\
\hline Pearson & 427.148 & 532 & 1.000 \\
Deviance & 475.488 & 532 & .962 \\
\hline
\end{tabular}

Table 3C. Model fitting information (MFI)

Source: Field survey (2017).

\begin{tabular}{|c|c|c|c|c|}
\hline \multirow{2}{*}{ Model } & \multirow{2}{*}{$\begin{array}{c}\text { Model-fitting criteria (MFC) } \\
-2 \log \text { likelihood }\end{array}$} & \multicolumn{3}{|c|}{ Likelihood ratio tests (LRT) } \\
\hline & & Chi-square & Df & Sig. \\
\hline Intercept only & 1193.184 & & & \\
\hline Final & 924.400 & 268.784 & 128 & .000 \\
\hline
\end{tabular}

Table 4C. Pseudo R-square

Source: Field survey 2017.

\begin{tabular}{lcc}
\hline & Results of Pseudo R-square & \\
\hline Cox and Snell & & .263 \\
Nagelkerke & & .298 \\
McFadden & 142 & \\
\hline
\end{tabular}

Table 5C. Likelihood ratio tests (LRT)

Source: Field survey (2017).

\begin{tabular}{|c|c|c|c|c|}
\hline \multirow[b]{2}{*}{ Effect } & \multirow{2}{*}{ 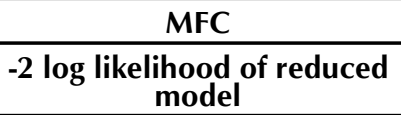 } & \multicolumn{3}{|c|}{ LRT } \\
\hline & & Chi-square & Df & Sig. \\
\hline Intercept & $924.400 a$ & .000 & 0 & \\
\hline GSF & 960.741 & 36.340 & 12 & .000 \\
\hline VSRU & 943.622 & 19.222 & 10 & .038 \\
\hline GSSTVS & 929.319 & 4.919 & 10 & .897 \\
\hline PGSTV & 937.236 & 12.835 & 12 & .381 \\
\hline DPIG & 945.504 & 21.104 & 12 & .040 \\
\hline SEBFG & 933.802 & 9.402 & 10 & .494 \\
\hline PERa & 930.089 & 5.688 & 6 & .459 \\
\hline PERb & 930.260 & 5.860 & 8 & .663 \\
\hline IPPFYa & 931.741 & 7.341 & 6 & .290 \\
\hline
\end{tabular}


Table 5C (cont.). Likelihood ratio tests (LRT)

\begin{tabular}{l|c|c|c|c}
\hline \multirow{2}{*}{ Effect } & \multicolumn{3}{|c}{ LRT } \\
\cline { 2 - 5 } & $\begin{array}{c}\text {-2 log likelihood of reduced } \\
\text { model }\end{array}$ & Chi-square & Df & Sig. \\
\hline IPPFYb & 954.470 & 30.070 & 8 & .000 \\
GSHHP & 932.972 & 8.572 & 10 & .573 \\
GSOV & 937.493 & 13.093 & 10 & .219 \\
\hline LPSS & 933.651 & 9.250 & 12 & .681 \\
\hline
\end{tabular}

Table 6C. Parameter estimate

Source: Field survey (2017).

\begin{tabular}{|c|c|c|c|c|c|c|}
\hline Stock choice & B & Std. error (SE) & Wald & Df & Sig & $\operatorname{Exp}(\beta)$ \\
\hline \multicolumn{7}{|c|}{$\begin{array}{l}\text { Value stock } \\
\end{array}$} \\
\hline Intercept & 20.417 & 4062.348 & 0.000 & 1 & 0.996 & \\
\hline GSF & -1.197 & 0.294 & 16.500 & 1 & 0.000 & 0.302 \\
\hline IP & -0.548 & 0.217 & 6.361 & 1 & 0.012 & 0.578 \\
\hline \multicolumn{7}{|c|}{ Undecided } \\
\hline Intercept & 0.929 & 6789.517 & 0.000 & 1 & 1.000 & \\
\hline VSRU & 2.084 & 0.905 & 5.300 & 1 & 0.021 & 8.037 \\
\hline DPIG & -1.719 & 0.730 & 5.544 & 1 & 0.019 & 0.179 \\
\hline
\end{tabular}

Table 7C. Classification

Source: Field survey (2017)

\begin{tabular}{l|c|c|c|c}
\hline \multirow{2}{*}{ Observed } & \multicolumn{4}{c}{ Predicted } \\
\cline { 2 - 5 } & Growth stock & Value stock & Undecided & Correct, \% \\
\hline Growth stock & 235 & 85 & 52 & 63.2 \\
\hline Value stock & 97 & 141 & 36 & 51.5 \\
\hline Undecided & 101 & 45 & 87 & 37.3 \\
\hline Overall, \% & 49.3 & 30.8 & 19.9 & 52.7 \\
\hline
\end{tabular}

\section{APPENDIX D. RELIABILITY TESTS}

Table 1D. Case processing summary

\begin{tabular}{ll|c|c}
\hline & & $\mathbf{N}$ & $\mathbf{\%}$ \\
\hline \multirow{3}{*}{ Cases } & Valid & 879 & 100.0 \\
& Excludeda & 0 & .0 \\
& Total & 879 & 100.0 \\
\hline
\end{tabular}

Note: a - Listwise deletion based on all variables in the procedure.

Table 2D. Reliability statistics 